\title{
WILD BARBERRY FRUIT (Berberis microphylla G. Forst.) AS A NATURAL INGREDIENT FOR BEER BREWING
}

\author{
María Laura Lemoine ${ }^{1 \mathrm{a} *}$, Ulises Fontana ${ }^{1 \mathrm{~b}}$, Jazmín B. Hurtado ${ }^{1 \mathrm{~b}}$, Federico M. Pintos ${ }^{1 \mathrm{c}}$, Miriam E. \\ Arena ${ }^{1 \mathrm{~d}}$, Ariel R. Vicente ${ }^{1 \mathrm{e}}$, and Luis M. Rodoni ${ }^{1 \mathrm{f}}$
}

1a Laboratorio de Investigación en Productos Agroindustriales (LIPA), Facultad de Cs. Agrarias y Forestales, Universidad Nacional de La Plata (UNLP), La Plata, Buenos Aires, Argentina. Consejo Nacional de Investigaciones Científicas y Técnicas (CONICET), Buenos Aires, Argentina https://orcid.org/0000-0002-8870-8366

${ }^{1 b}$ Laboratorio de Investigación en Productos Agroindustriales (LIPA), Facultad de Cs. Agrarias y Forestales, Universidad Nacional de La Plata (UNLP), La Plata, Buenos Aires, Argentina

1c Laboratorio de Investigación en Productos Agroindustriales (LIPA), Facultad de Cs. Agrarias y Forestales, Universidad Nacional de La Plata (UNLP), La Plata, Buenos Aires, Argentina. Consejo Nacional de Investigaciones Científicas y Técnicas (CONICET), Buenos Aires, Argentina

1d Universidad de Morón, Laboratorio de Fisiología Vegetal, Morón, Buenos Aires, Argentina. Consejo Nacional de Investigaciones Científicas y Técnicas (CONICET), Buenos Aires, Argentina

1e Laboratorio de Investigación en Productos Agroindustriales (LIPA), Facultad de Cs. Agrarias y Forestales, Universidad Nacional de La Plata (UNLP), La Plata, Buenos Aires, Argentina. Consejo Nacional de Investigaciones Científicas y Técnicas (CONICET), Buenos Aires, Argentina https://orcid.org/0000-0003-1289-9554

${ }_{1 f}$ Laboratorio de Investigación en Productos Agroindustriales (LIPA), Facultad de Cs. Agrarias y Forestales, Universidad Nacional de La Plata (UNLP), La Plata, Buenos Aires, Argentina. Consejo Nacional de Investigaciones Científicas y Técnicas (CONICET), Buenos Aires, Argentina https://orcid.org/0000-0003-4409-6211

* Corresponding Author: E-mail: mllemoine@agro.unlp.edu.ar

\section{ABSTRACT}

Barberry (Berberis microphylla) is a wild berry endemic to the Andean-Patagonian zone of Argentina and Chile. Even though it is not widely used or consumed, it has great potential for coloring and enrichment of different food matrices due to its high anthocyanin and antioxidant contents. The objective of this study was to evaluate the impact of barberry addition on quality parameters and stability of sour beer. Nutritional, physicochemical and sensory characteristics of the beer were analyzed. Firstly, different amounts of freeze-dried barberry were added to sour beer (0, 2.5, 5, and $10 \mathrm{~g} \mathrm{~L}^{-1}$ ) after primary fermentation. In the next experiment, beers brewed with 0 (control) and $5 \mathrm{~g} \mathrm{~L}^{-1}$ of barberry were stored at $5^{\circ} \mathrm{C}$ for up to 90 days and evaluated on a monthly basis. As demonstrated by the CIE Lab and $\mathrm{Abs}_{520 \mathrm{~nm}}$ parameters, barberry addition resulted in a marked color shift towards ruby red tones. It also increased TEAC and phenolic contents by 2-4 times, without affecting beer $\mathrm{pH}$, acidity, or density. Furthermore, it had a positive impact on overall impression, appearance, aroma, flavor and balanced scores in a trained sensorial panel. Beer total anthocyanins varied between 30 and $100 \mathrm{mg}$ D3G $\mathrm{L}^{-1}$. The beers brewed with barberry fruit presented stable antioxidant capacity, total anthocyanin content and both anthocyanin ionization and polymerization degree during storage. The results show that barberry can be used as an ingredient to make red and antioxidant-enriched sour beers with good stability during storage.

Key words: "calafate", Andean, red-beverage, berry, antioxidants. 


\section{INTRODUCTION}

Berberis microphylla G. Forst. is an evergreen non-timber species naturally growing in the Argentine-Chilean Andean-Patagonian forest. The spiny shrub yields tiny purple berries (barberry-fruit), which are several-fold richer in anthocyanins and antioxidants than many of the so-called "super fruits", such as blueberry (Vaccinium corymbosum) (Rodoni et al., 2014) and murtilla (Ugni molinae) (Ruiz et el., 2010). Traditionally, barberry has been used for jams and infusions by local populations, and for cosmetics by the industry. Due to its colorant and antioxidant properties, it can be an attractive food ingredient but evaluation is required in each particular food matrix.

Beer is the most widely consumed alcoholic beverage in the world, and the third-mostpopular drink after water and tea (Guido, 2019). Microbreweries have been one of the highest growth drivers for the beer market, gaining momentum in local markets and international trade share (Yeo and Liu, 2014). Though still dwarfed by India Pale Ale (IPA), sour beers such as Belgian Lambic, Flanders and German Berliner Weisse are quickly becoming one of the most produced beer styles (Strong and England, 2015; Chervina et al., 2019). Their clean lactic acidity is achieved through lactic-fermented wort, with specific lactic acid bacteria culture added before primary fermentation (Dysvik et al., 2019). The low bitterness and alcohol content of many of these styles contribute to their refreshing profile (Strong and England, 2015).

Many brewers have experimented with new ingredients in their formulations, leading to an innovative social process in the beer and craftbeer industry (Forde, 2017). In fact, the use of raw materials other than malt, hops, yeast and water has been a common approach for novel beer formulations (Schuina et al., 2020). Fruits, along with vegetables, spices and flowers, are the most frequently used ingredients for that purpose (Strong and England, 2015). While fruits can be added to almost any beer style, brewers usually prefer to add them to sour beer because fruit flavors taste more natural (Tonsmeire, 2014). Besides, a lot of fruits are an antioxidant source (Jin et al., 2014; Martínez et al., 2017a), and thus fruit addition can increase beer addedvalue, bioactive compounds and antioxidant power. Furthermore, a high antioxidant activity may be favorable to reduce oxidative reactions, preserving sensory characteristics of beer during storage (Caballero et al., 2012).

Some studies have evaluated the impact of brewing with fruits (Martínez et al., 2017b; Kawa-
Rygielska et al., 2019) and vegetables (Horincar et al., 2020) on beer physicochemical characteristics and antioxidant capacity. However, there is little information on the impact of fruit addition on the quality and antioxidant properties of sour beer. Therefore, the objective of this study was to evaluate the impact of barberry addition on the quality parameters and stability of a novel sour ale beer. Physicochemical properties, anthocyanin levels, antioxidant capacity and sensory properties were analyzed.

\section{MATERIALS AND METHODS}

\section{Plant material}

Barberry fruit (Berberis microphylla) was harvested from a wild population located near Ushuaia city $\left(54^{\circ} 48^{\prime}\right.$ S.; $68^{\circ} 19^{\prime}$ W., Tierra del Fuego, Argentina) in early 2019. The fruit was refrigerated and transported to the laboratory for analysis. The fresh fruits had $20^{\circ} \mathrm{Brix}, \mathrm{pH}$ of 3.4 , acidity of $17 \mathrm{~g} \mathrm{~kg}^{-1}$ (as malic acid equivalents) and a water content of $720 \mathrm{~g} \mathrm{~kg}^{-1}$ (fresh wet basis). At the laboratory, the fruit was washed with sodium hypochlorite (150 mg kg-1, pH 6.5 for $1 \mathrm{~min}$ ), and then rinsed three times with tap water, frozen in liquid nitrogen, crushed in a mill and frozen at $-80^{\circ} \mathrm{C}$. The obtained powder was freeze-dried (RIFICOR, L-A-B3, Bs. As. Argentina) at $35^{\circ} \mathrm{C}$ and $2.13 \mathrm{mbar}$ for $48 \mathrm{~h}$ and stored at $-20^{\circ} \mathrm{C}$ until use. The samples were dried at $105^{\circ} \mathrm{C}$ to constant mass (AOAC, 2012) and dry matter content was determined. The moisture content in the final product was $170 \mathrm{~g} \mathrm{H}_{2} \mathrm{O} \mathrm{kg}^{-1}$ wet basis. Freezedried barberry fruit was used for the experiments.

\section{Beer manufacturing}

A sour beer (Berliner Weisse) was brewed at LAURUS $^{\circledR}$ craft beer company located in La Plata, Argentina. Ten kilograms of a mixture containing $50 \%$ Pilsner barley malt (Sacha Maltería Platense, Argentina) and 50\% wheat malt (Maltear, Argentina) were ground. Mashing water was filtered through a reverse osmosis system (Romin Ingenieria, Serie Riepro 800, Argentina). The following compounds were added to osmosis water $(55 \mathrm{~L}): 0.054 \mathrm{~g} \mathrm{~L}^{-1}$ of $\mathrm{CaCl}_{2}, 0.018 \mathrm{~g} \mathrm{~L}^{-1}$ of $\mathrm{CaSO}_{4^{\prime}} 0.013 \mathrm{~g} \mathrm{~L}^{-1}$ of $\mathrm{CaCO}_{3^{\prime}} 0.013 \mathrm{~g} \mathrm{~L}^{-1}$ of $\mathrm{MgSO}_{4}$ and $0.27 \mathrm{~g} \mathrm{~L}^{-1}$ of phosphoric acid. Mashing was conducted at $67^{\circ} \mathrm{C}$ for $90 \mathrm{~min}$, adjusting the $\mathrm{pH}$ to 5.5 and obtaining a specific gravity of 1.048 . The grain was washed with $25 \mathrm{~L}$ osmosis water at $78^{\circ} \mathrm{C}$ to remove residual sugar; the final volume of the batch was $80 \mathrm{~L}$. The wort was boiled for 15 min to eliminate the microbial flora and quickly cooled to $35^{\circ} \mathrm{C}$. For kettle souring, a culture of Lactobacillus plantarum (Wild Brew TM Sour Pitch Lallemand, Canada) was used. The wort was 
rehydrated with sterile osmosis water at $25^{\circ} \mathrm{C}$, and then the culture was added at $35^{\circ} \mathrm{C}$. The wort initial $\mathrm{pH}$ was 5.4 at $35^{\circ} \mathrm{C}$ dropping to 3.4 after $24 \mathrm{~h}$ of incubation. Subsequently, the wort was boiled for $60 \mathrm{~min}$, adding $30 \mathrm{~g}$ of hop pellets (Crystal variety, United States) and yeast nutrients (Servomyces, Lallemand Brewing, Canada) 15 minutes before boiling ended. An original gravity of 1.037 was obtained. After boiling, the whirlpool was conducted. For primary fermentation, the wort was cooled quickly to $18{ }^{\circ} \mathrm{C}$, poured into fermenters as described below and inoculated with Saccharomyces cerevisiae yeast (Ale Nottingham, Lallemand, Canada) at a rate of $0.8 \mathrm{~g} \mathrm{~L}^{-1}$ after its activation in sterile water at $25^{\circ} \mathrm{C}$ for 30 minutes. Two independent experiments were conducted.

\section{Fruit addition}

Once primary fermentation was completed (final gravity 1.010), the beer was split into 4 groups of $5 \mathrm{~L}$ fermenters each and freeze-dried barberry was added at 0 (control), 2.5, 5, and 10 $\mathrm{g} \mathrm{L}^{-1}$. $\mathrm{CO}_{2}$ was bubbled through the beers for 10 min to ensure correct distribution and favor fruit component extraction, avoiding $\mathrm{O}_{2}$ incorporation and oxidation. The beers were maintained at 10 ${ }^{\circ} \mathrm{C}$ for five days, and then transferred and kept at $5{ }^{\circ} \mathrm{C}$ for $2 \mathrm{~d}$ for clarification. Three replicates were used for each treatment. After clarification, the beers were carbonated with $\mathrm{CO}_{2}$ and bottled under pressure in $340 \mathrm{~mL}$ caramel-colored glass bottles. After $2 \mathrm{~d}$ at $5{ }^{\circ} \mathrm{C}$, samples were taken and evaluated.

\section{Beer storage}

A sour beer brewed with $5 \mathrm{~g} \mathrm{~L}^{-1}$ of freeze-dried barberry powder was prepared as described above. The bottled product was stored at $5{ }^{\circ} \mathrm{C}$ in darkness for $0,30,60$ and $90 \mathrm{~d}$. At each storage time, beer was sampled and the following parameters were evaluated: color, $\mathrm{pH}$, acidity, density, contents of anthocyanin and phenolic compounds, and antioxidant activity using Trolox equivalent antioxidant capacity (TEAC). A sensory analysis was also performed.

\section{Quality assessments}

Sample degassing. Samples were frozen and conserved at $20^{\circ} \mathrm{C}$ until use. For color, $\mathrm{pH}$, acidity, soluble solids, density, total phenolic content, anthocyanin content, ionization, browning and polymerization, and antioxidant capacity determinations, the samples were thawed and vortex-shaken for $10 \mathrm{~min}$ to expel the remainder $\mathrm{CO}_{2}$. For each assessment, three measurements were made for each beer replicate and the values were averaged.

European Brewery Convention (EBC) color, red color component and color density. One milliliter of degassed beer was poured into 1 $\mathrm{cm}$ glass cuvette. The sample was analyzed spectrophotometrically (Numak, Model 721, China). Absorbance was measured at 420, 430, 520 and $700 \mathrm{~nm}$ using distilled water as reference. Color was determined using the European Brewery Convention (EBC) method. Estimations were made as follows:

$$
\begin{aligned}
& E B C \text { color }=(A b s 430-A b s 700) \times 25 \\
& \text { Red color }=(\text { Abs520-Abs700) } \\
& \text { Color density }=(\text { Abs420-Abs700) }+ \\
&(\text { Abs520-Abs700) }
\end{aligned}
$$

Color. Beer color was determined with a colorimeter (Minolta, Model CR-300, Osaka, Japan) equipped with an immersion head. A volume of 10 milliliters of the degassed sample was poured in a $2 \mathrm{~cm}$ diameter and $2 \mathrm{~cm}$ high cylindrical opaque cuvette, where the colorimeter head was immersed. The CIE Lab color parameters $\left(L^{*}, a^{*}\right.$ and $\left.b^{*}\right)$ were recorded. Three measurements were conducted for each replicate and the values obtained were averaged.

pH, acidity, ${ }^{\circ}$ Brix and density. Samples of degassed beer were used. The $\mathrm{pH}$ was determined using a pHmeter (Numak, PHS-3E, China) (AOAC, 981.12 method, 2012). A digital refractometer (Milwaukee, MA871) was used for ${ }^{\circ}$ Brix measurements. For acidity evaluation, 10 $\mathrm{mL}$ of beer were brought to $100 \mathrm{~mL}$ with distilled water and titrated with $\mathrm{NaOH} 0.1 \mathrm{~mol} \mathrm{~L}^{-1}$ until reaching $\mathrm{pH}$ : 8.2. Acidity was expressed in $\mathrm{g}$ of lactic acid equivalents $\left[\mathrm{H}^{+}\right]$per liter. Density was measured using a densimeter and expressed as specific gravity. All measurements were made in triplicate.

Anthocyanins. Anthocyanin content was measured by the differential $\mathrm{pH}$ method (Horincar et al., 2020). Degassed beer samples were diluted with $\mathrm{KCl}$ buffer $(0.025 \mathrm{M}$, $\mathrm{pH}$ : 1$)$ or with sodium acetate buffer $\left(0.4 \mathrm{~mol} \mathrm{~L}^{-1}, \mathrm{pH}: 4.5\right)$. The absorbance of both solutions was measured at $520 \mathrm{~nm}$ (Numak, Model 721, China) in a $1 \mathrm{~cm}$ cuvette. Anthocyanin content was calculated using extinction coefficient for delphinidin-3glucoside, $\varepsilon=0.051 \mathrm{~L} \mathrm{mg}^{-1} \mathrm{~cm}^{-1}$. Anthocyanin content was expressed as $\mathrm{mg}$ of delphinidin-3glucoside (D3G L $\left.{ }^{-1}\right)$ :

$$
D 3 G=(A \times D F-B \times D F) \times \varepsilon^{-1} \times 1 \mathrm{~cm}^{-1}
$$

where: $\mathrm{A}:\left(\mathrm{Abs}_{520 ; \mathrm{pH}: 1}-A b s_{700 ; \mathrm{pH}: 1}\right)$; B: $\left(\mathrm{Abs}_{520 ; \mathrm{pH}: 4,5}-A b s_{700 ;}\right.$
pH:4,5) ; DF: dilution factor. 
Anthocyanin ionization, polymeric color and browning index. The absorbance of an aliquot portion of degassed beer was measured at 520 nm (Numak, Model 721, China). A second aliquot portion was diluted with $\mathrm{KCl}$ buffer, at $\mathrm{pH}<1$, and the absorbance was measured at 520 $\mathrm{nm}$. The proportion of anthocyanin in its ionized flavylium form was estimated reading the absorbance of beer $(\mathrm{pH} \approx 3.4)$ and acidified beer $(\mathrm{pH}<1)$ The result was expressed as a percentage of ionized anthocyanin (\%ionized anthocyanin) and was calculated as follow:

$$
\% \text { ionized anthocyanin }=100 \times A \times(B \times D F)^{-1}
$$

where:

$$
\begin{aligned}
& \mathrm{A}:\left(\mathrm{Abs}_{520} \mathrm{pH}\right. \text { of beer } \\
& \left.\mathrm{Abs}_{700 ;} \mathrm{AbS}_{701}\right) ; \mathrm{DF} \text { : dilution factor } \mathrm{pH} \text { of ber }
\end{aligned}
$$

Anthocyanin degradation products were measured by polymeric color assay. The degassed beer sample was diluted with distilled water. A 2.8 $\mathrm{mL}$-aliquot portion of the dilution was placed in a test tube and $0.2 \mathrm{~mL}$ of $\mathrm{K}_{2} \mathrm{~S}_{2} \mathrm{O}_{5}(20 \% \mathrm{p} / \mathrm{v}$, freshly prepared) was added. The solution was mixed in a vortex and, absorbance was measured after 15 minutes at 420 and $520 \mathrm{~nm}$. Polymerization index (PI) was calculated as follow:

$$
P I=\left(A b s_{420} x D F+A b s_{520} x D F\right)
$$

where DF is the dilution factor.

Based on an aliquot portion of the degassed beer, browning was calculated as the ratio between the absorbance measured at wavelengths of 430 and $520 \mathrm{~nm}$ corresponding to the browning index (BI):

$$
B I=\left(\frac{A b s_{430}}{A b s_{520}}\right)
$$

Trolox equivalent antioxidant capacity (TEAC). Measurements were made according to GómezGarcía et al. (2021). Absorbance at $734 \mathrm{~nm}$ was measured using a spectrophotometer (Numak, Model 721, China) after $6 \mathrm{~min}$ of incubation. Trolox was used as a standard and the results were expressed as Trolox equivalent $\left(\mathrm{mg} \mathrm{TE} \mathrm{L}^{-1}\right)$ on a fresh weight basis.

Phenolic compounds. Total phenolic content was determined by Folin-Ciocalteu reagent (Petrón et al., 2021) using gallic acid as a standard; absorbance was read at $760 \mathrm{~nm}$ (Numak, Model 721, China). The results were expressed as gallic acid equivalents (mg GAE L-1) on a fresh weight basis.

Sensory analysis. The beers brewed with different amounts of barberry fruit were sensory evaluated by a panel of four judges certified by the Beer Judge Certification Program (BJCP). Overall impression, appearance, aroma, flavor, sourness, and balanced attributes were evaluated using a 10-point hedonic scale. The control and barberry enriched $\left(5 \mathrm{~g} \mathrm{~L}^{-1}\right)$ beers were evaluated after 0 and $90 \mathrm{~d}$ storage.

\section{Statistical analysis}

A factorial design was used. For the selection between beers brewed with barberry, the factor was the amount of fruit added. For the storage assay, the factors were the amount of fruit added and storage time. The statistical unit was each fermenter $(n=3)$.

Mean values (of three replicates) and standard deviation were calculated. The means were compared using an analysis of variance (ANOVA) and Tukey test at a level of significance of $p<0.05$. The linear relationship strength between two variables was calculated by the Pearson correlation.

\section{RESULTS AND DISCUSSION}

\section{Influence of barberry addition on beer physicochemical and sensory properties}

Barberry is an excellent ingredient for anthocyanin enrichment of beverages due to its exceptionally high anthocyanin content. In the present study, anthocyanin reached levels of $11.0 \pm 0.1(n=4)$ and $30.0 \pm 1.1(n=4) \mathrm{g} \mathrm{D} \mathrm{G} \mathrm{kg} \mathrm{kg}^{-1}$ on a fresh weight basis in fresh and lyophilized fruit, respectively. These values are 10 and 15 times higher than those reported for blueberry and eggplant (Solanum melongena), which are recognized as anthocyanin-rich sources (Sadowska et al., 2017; Horincar et al., 2020), and comparable with other so-called super-fruits like maqui (Aristotelia chilensis), black chokeberry (Aronia melanocarpa) and bilberry (Vaccinium myrtillus L.) (Ruiz et al., 2010; Sadowska et al., 2017).

As expected, barberry addition resulted in a noticeable color shift (from golden to red hues) in the beers, which varied depending on the amount of fruit added (Fig. 1A). The high anthocyanin content in barberry powder caused an extensive color change with relatively low fruit addition. The beer color for the control (no fruit added) and for the treatments with 2.5, 5 and $10 \mathrm{~g} \mathrm{~L}^{-1}$ of fruit added corresponded to 6 (the red color component was almost nil), 10.3, 13.5 and 23.5 EBC units, respectively (Fig. 1B and 1C). Furthermore, the addition of barberry resulted in an increase in EBC units, probably explained by the broad anthocyanin absorbance range at wavelengths less than $430 \mathrm{~nm}$ (Ahliha et al., 


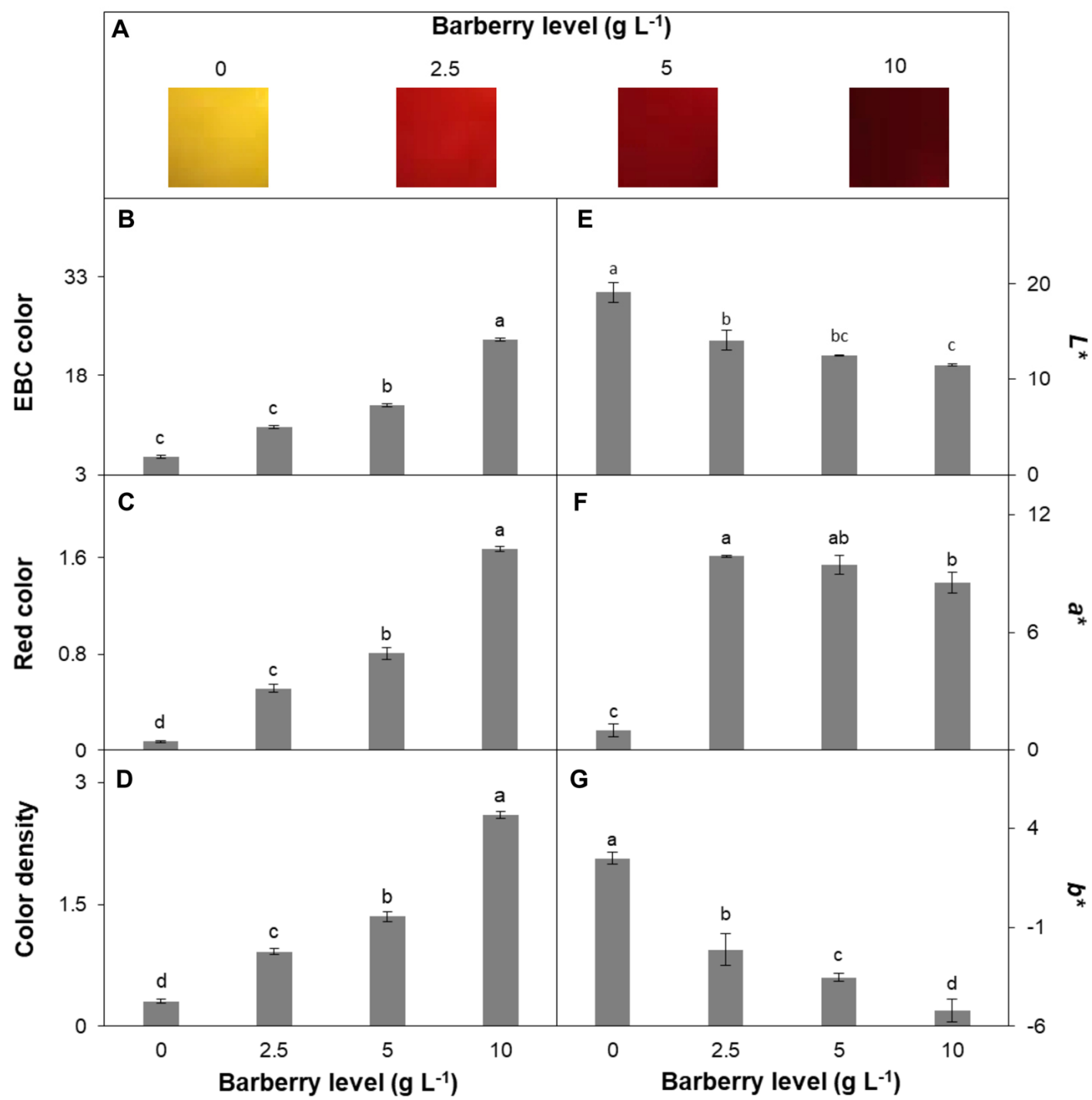

Fig. 1. A. Visual appearance; B. European Brewing Color (EBC color); C. Red color component; D. Color density; E. Lightness $\left(L^{*}\right) ; \mathrm{F} . a^{*}$ and G. $b^{*}$ color values of sour beer enriched with 0 (control), 2.5, 5 and $10 \mathrm{~g} \mathrm{~L}^{-1}$ of freeze-dried barberry fruit. Means \pm standard errors are shown. Letters indicate significant differences based on a Tukey test at a significance level of $p<0.05$.

2018). In a previous study, quince fruit (Cydonia oblonga Miller) addition to American amber ale beer slightly increased EBC color (Zapata et al., 2019). In the present study, barberry addition caused a significant increase in both the red color component and color density in direct association with barberry level $(R=0.998 ; p=0.000)$ (Fig. $1 \mathrm{C}$ and 1D). A marked drop in beer $L^{*}$ from 19 to 11 was found with $10 \mathrm{~g} \mathrm{~L}^{-1}$ of barberry (Fig. 1E). Barberry caused opposite trends in $a^{*}$ and $b^{*}$ color beer parameters, which was in line with an increment in red and blue components, respectively (Fig. $1 \mathrm{~F}$ and $1 \mathrm{G})$. The highest $\Delta \mathrm{a}^{*}$ was observed in the beer with the lowest amount of fruit added (2.5 $\mathrm{g} \mathrm{L}^{-1}$ ), without further relevant increases with higher fruit levels. In contrast, the $b^{*}$ component was reduced when fruit level increased $(R=0.913$; $p=0.001$ ).

Horincar et al. (2020) also observed a decrease in $L^{*}$ and an increase in $a^{*}$ in lager beer enriched with eggplant skin powder. However, the authors also reported an increase in $b^{*}$. This difference may be due to the presence of anthocyanins in the yellow chalcone form related to the high beer $\mathrm{pH}(\sim 4.5)$ used in the study. Barberry addition leads to novel hue varieties that can be selected by controlling the amount of fruit added in the brewing process, becoming a new and interesting 
ingredient for beer brewing.

The final $\mathrm{pH}$ was around 3.4 and did not vary with barberry addition (Table 1). This may be due to the close $\mathrm{pH}$ values of barberry fruit and sour beer. Contrarily, organic acids for Hibiscus sabdariffa flowers (Martínez et al., 2017a) or cornelian cherry (Cornus mas L.) (Kawa-Rygielska et al., 2019) dropped the beer $\mathrm{pH}$. Increases in acidity, ${ }^{\circ}$ Brix and density were observed with $10 \mathrm{~g}$ $\mathrm{L}^{-1}$ of fruit added (Table 1), which is in agreement with previous studies (Ulloa et al., 2017; Horincar et al., 2020). The additional sugar incorporated with the fruit can lead to over-carbonation of beer, especially with high fruit levels and when stored above refrigeration temperatures (Wray, 2020).

Barberry allowed obtaining beers with 30-100 mg D3G $\mathrm{L}^{-1}$ of anthocyanins, varying with the amount of fruit added $(R=0.997 ; p=0.000)$ (Fig. $2 A)$. Similar anthocyanin concentration was achieved in beer with dried eggplant skin added (Horincar et al., 2020). In barberry fruit, anthocyanin/total solid ratio is close to $40 \mathrm{~g} \mathrm{~kg}^{-1}$, which is higher than that of other fruits like raspberry (Rubus idaeus L.), blueberry or blackberry (Rubus fruticosus L.), with values of 4.2; 12 and 21, respectively (Sadowska et al., 2017). This allowed increasing anthocyanin levels, without adding a high load of other solids that could affect beer characteristics.

Antioxidants like phenolic acids, flavonoids and proanthocyanidins are naturally present in beer (Wannenmacher et al., 2018). The use of fruit, herbs, spices and other unconventional ingredients in beer brewing comes from the search for new beers styles, with novel colors and flavors (Tonsmeire, 2014). In fact, antioxidantrich fruit can add natural antioxidants that may contribute to protect beer quality, hindering undesirable oxidative reactions (Martínez et al., 2017a). In this sense, there is an increasing interest in beer enrichment with healthy biological active compounds (Ulloa et al., 2017; Horincar et al., 2020). A study conducted by Kawa-Rygielska et al. (2019) revealed that cornelian-fruit resulted in beers with higher phenolic compounds $(70 \%)$ and antioxidant activity when added after rather than before primary fermentation. Based on this, barberry fruit was added after primary fermentation to obtain the highest possible value added.

In terms of antioxidant capacity, the barberry beer with $2.5 \mathrm{~g} \mathrm{~L}^{-1}$ fruit added was 2-fold higher than the control (Fig. 2B). Higher fruit addition caused lower, but still significant increases, which indicates that there is some interaction between fruit antioxidants and some beer components. Despite the nature and extent of such interactions, which prevented a proportional increase in antioxidant capacity with the level of fruit incorporation, the beer with $10 \mathrm{~g} \mathrm{~L}^{-1}$ of barberry added recorded an antioxidant level that was four times higher than that of the control (Fig. 2B). The increase in beer antioxidant capacity correlated with the level of anthocyanins $(R=0.951 ; P=0.000)$ (Fig. 2A and 2B).

Levels of total phenolic compounds vary with the ingredients and brewing practices used. Depending on the beer style, $70-80 \%$ of them derive from malt and the rest from hops (Wannenmacher et al., 2018). The literature has already described that fruit addition can be a relevant source of phenolic compounds in fruitbeer styles (Kawa-Rygielska et al., 2019). In commercial beer, levels vary greatly from 22 to $300 \mathrm{mg} \mathrm{L}^{-1}$ depending on the beer type (Zhao et al., 2010; Patraşcu et al., 2018), but the presence of synthetic antioxidants may contribute to these differences. In the present study, the finished beer with 0 (control beer), 2.5, 5 and $10 \mathrm{~g} \mathrm{~L}^{-1}$ of barberry recorded total phenolic compounds of 152, 276, 300 and $360 \mathrm{mg} \mathrm{L}^{-1}$, respectively (Fig. 2C). These results show that low levels of barberry added could be used to yield red-colored antioxidantrich beer, without affecting product density or $\mathrm{pH}$. In terms of anthocyanins, levels were high and comparable with those commonly found in

Table 1. $\mathrm{pH}$, titratable acidity and density of sour beer enriched with 0 (control), 2.5, 5 and $10 \mathrm{~g} \mathrm{~L}^{-1} \mathrm{of}$ freeze-dried barberry fruit.

\begin{tabular}{lcccc}
\hline Parameter & \multicolumn{4}{c}{ Barberry added $\left(\mathrm{g} \mathrm{L}^{-1}\right)$} \\
\hline & 0 & 2.5 & 5 & 10 \\
pH & $3.44 \pm 0.03 \mathrm{a}$ & $3.44 \pm 0.02 \mathrm{a}$ & $3.45 \pm 0.01 \mathrm{a}$ & $3.41 \pm 0.01 \mathrm{a}$ \\
Acidity $\left(\mathrm{g} \mathrm{L}^{-1}\right)$ & $5.7 \pm 0.5 \mathrm{~b}$ & $6.0 \pm 0.1 \mathrm{~b}$ & $6.1 \pm 0.5 \mathrm{~b}$ & $7.1 \pm 0.1 \mathrm{a}$ \\
oBrix & $5.3 \pm 4 \times 10^{-2} \mathrm{C}$ & $5.4 \pm 5 \times 10^{-2} \mathrm{~b}$ & $5.5 \pm 1 \times 10^{-2} \mathrm{~b}$ & $5.7 \pm 1 \times 10^{-2} \mathrm{a}$ \\
Specific gravity & $1.010 \pm 7 \times 10-4 \mathrm{~b}$ & $1.011 \pm 2 \times 10^{-4} \mathrm{ab}$ & $1.011 \pm 3 \times 10^{-4} \mathrm{ab}$ & $1.012 \pm 1 \times 10^{-4} \mathrm{a}$ \\
\hline
\end{tabular}

The means \pm standard errors are shown $(n=3)$. Letters indicate significant differences based on a Tukey test at a significance level of $p<0.05$.

Se muestran las medias \pm error estándar $(n=3)$. Valores con letras distintas indican diferencias según test de Tukey con un nivel de significancia $p<0.05$. 


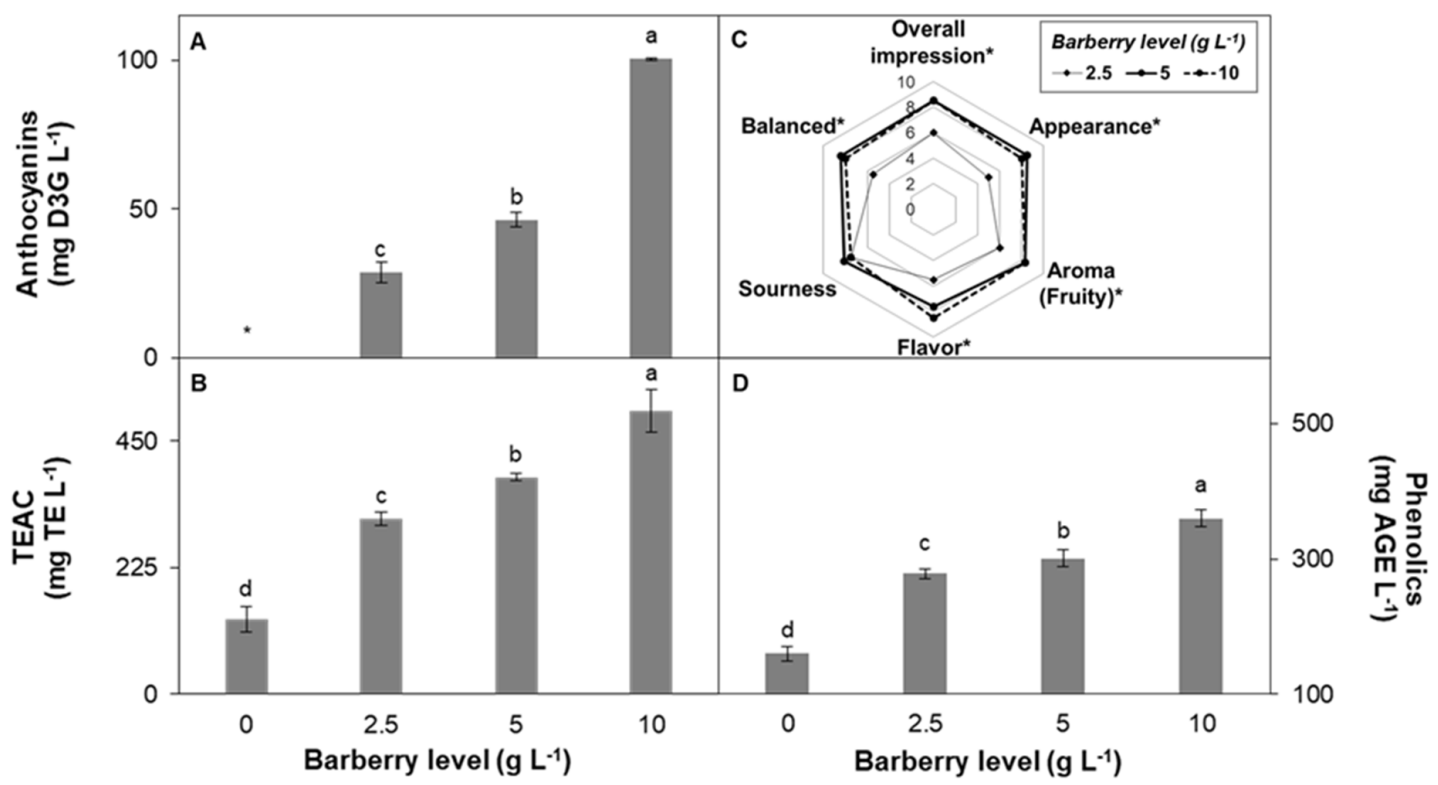

Fig. 2. A. Anthocyanins; B. Antioxidant capacity (TEAC); C. Sensory scores of barberry beer enriched with 2.5, 5 and $10 \mathrm{~g} \mathrm{~L}^{-1}$ of freeze-dried barberry fruit; D. Phenolic compounds of sour beer enriched with 0 (control), 2.5, 5 and $10 \mathrm{~g} \mathrm{~L}^{-1}$ of freeze-dried barberry fruit. Means \pm standard errors and means are shown in the bar and spider graphs, respectively. Letters or asterisks indicate significant differences based on a Tukey test at a significance level of $p<0.05$.

grape juices (Muche et al., 2018).

Brewers need to get unbiased feedback on their beers. Given the hundreds of beer styles available at present, there is a tendency to evaluate beers within certain criteria or styles (Fitzpatrick et al., 2017). The Beer Judge Certification Program (BJCP)-authorized competitions currently include the 'fruit-beer' style (Tonsmeire, 2014; Strong and England, 2015). When barberry beers were evaluated accordingly, the beers with 5 and $10 \mathrm{~g}$ $\mathrm{L}^{-1}$ of barberry added recorded the highest scores (Fig. 2D). The $5 \mathrm{~g} \mathrm{~L}^{-1}$ barberry-fruit level resulted in antioxidant-enriched beers with high attributes within the fruit beer style, and thus it was chosen for subsequent analyses.

\section{Changes in beer quality during storage}

Increasing consumer concern about the use of synthetic additives has led to the search for natural pigments as coloring agents for different food matrices. Anthocyanins have been a promising alternative due to their high water solubility, dyeing capacity, antioxidant activity and health benefits (Horincar et al., 2020; Jin et al., 2014). However, they have shown lower stability compared to synthetic additives (Ertan et al., 2020), $\mathrm{pH}$ dependence on both color and stability (West and Mauer et al., 2013), and potential undesirable interactions with other food components. The most widely used colorant is caramel, mainly for minor adjustments in the brewing process or ingredients. In general, the use of other pigments other than caramel is related to fruit-beer styles. To our knowledge, few studies have evaluated anthocyanin stability in beer, while there is no information on the quality of sour beers during storage. In this sense, a trend to aging and color degradation has been reported (Martínez et al., 2017a).

In the present study, the beers with 0 (control) and $5 \mathrm{~g} \mathrm{~L}^{-1}$ of barberry added were bottled and stored at $5^{\circ} \mathrm{C}$ for 3 months and sampled on a monthly basis. Beer quality during storage was evaluated focusing on anthocyanin stability and antioxidant capacity. The $\mathrm{pH}$ values of both beers was around 3.4 and did not vary during storage. As $\mathrm{pH}$ is closely related to physicochemical and microbiological beer stability, it is desirable to be constant during storage. The acidity was 6.3-7.0 $\mathrm{g} \mathrm{L} \mathrm{L}^{-1}$ and the specific gravity ranged between 1.009 and 1.011. The EBC color of the control and barberry beers was 6 and 11 before storage, respectively (Fig. 3A). During storage, a slight increase in the EBC color was observed. There were no relevant changes in either the red color component or color density of the control beer during storage (Fig. 3B and 3C). However, a reduction of $15 \%$ in barberry beer red color was observed after $30 \mathrm{~d}$ storage (Fig. 3B), while no further changes were detected afterwards. 


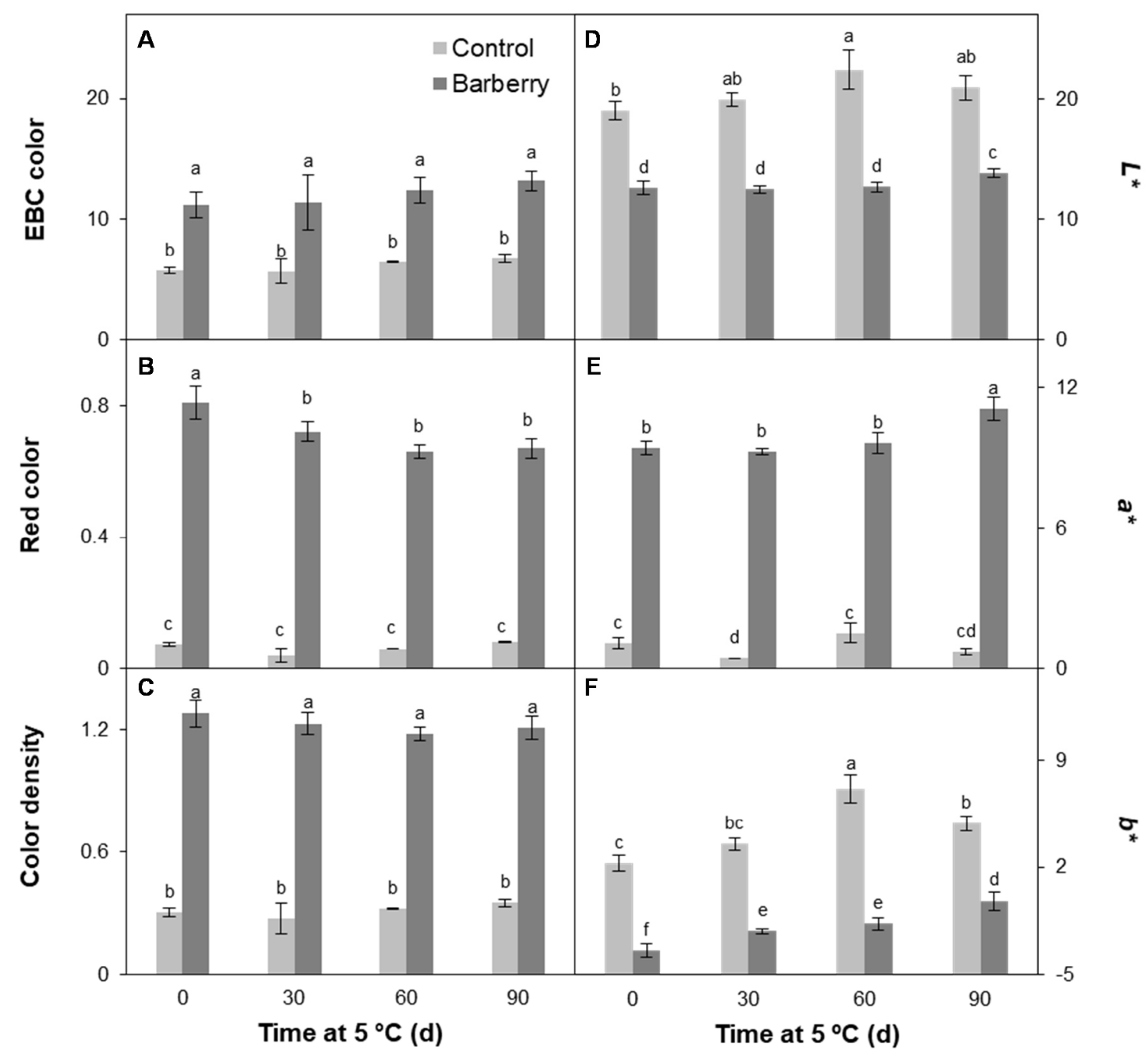

Fig. 3. A. European Brewing Color (EBC color); B. Red color component; C. Color density; D. Lightness $\left(L^{*}\right) ; \mathrm{E} . a^{*}$ and F. $b^{*}$ color values of control and barberry $\left(5 \mathrm{~g} \mathrm{~L}^{-1}\right)$ beers after bottle storage at $5^{\circ} \mathrm{C}$ for $0,30,60$ and $90 \mathrm{~d}$. Mean \pm standard errors are shown. Letters indicate significant differences based on a Tukey test at a significance level of $p<0.05$.

A similar trend was observed in terms of color density (Fig. 3C).

Initial luminosity $\left(L^{*}\right)$ was 19 and 12.5 for the control and barberry beer, respectively. Beer luminosity tended to increase by 1-2 units, with a more noticeable increase in the control (Fig. 3D). The control showed an increasing trend in yellow $\left(b^{*}\right)$ component until $60 \mathrm{~d}$ with a subsequent drop until $90 \mathrm{~d}$ (Fig. 3F). A study on Pilsen beer enriched with eggplant skin reported that both $a^{*}$ and $b^{*}$ parameters decreased as storage time increased, which was attributed to low anthocyanin stability (Horincar et al., 2020). In contrast, we observed an increasing trend in $a^{*}$ and $b^{*}$ in the barberry beer (Fig. 3E and 3F). In addition, anthocyanin concentration was c.a. 45 mg D3G $\mathrm{L}^{-1}$, without significant changes during storage (Fig. 4A). These results do not agree with other studies that have described anthocyanin instability during beer storage. For example, Martínez et al. (2017a) found that beers brewed with 5 and $20 \mathrm{~g} \mathrm{~L}^{-1}$ of hibiscus recorded 40 and $13 \%$ decreases in total monomeric anthocyanins, respectively, after accelerated storage (7 days at $45^{\circ} \mathrm{C}$ ). Another study in beer brewed with 5 $\mathrm{g} \mathrm{L}^{-1}$ of eggplant peels and kept refrigerated at $5^{\circ} \mathrm{C}$ failed to prevent anthocyanin degradation, decreasing from 44 to $30 \mathrm{mg} \mathrm{L}^{-1}$ after $21 \mathrm{~d}$ storage (Horincar et al., 2020). The molecular structure of anthocyanins influences their chemical stability, with mono-glycosylated forms being less stable than poly-glycosylated and acetylated forms (Ertan et al., 2020). In barberry fruit, anthocyanins are not the most stable compounds in terms 


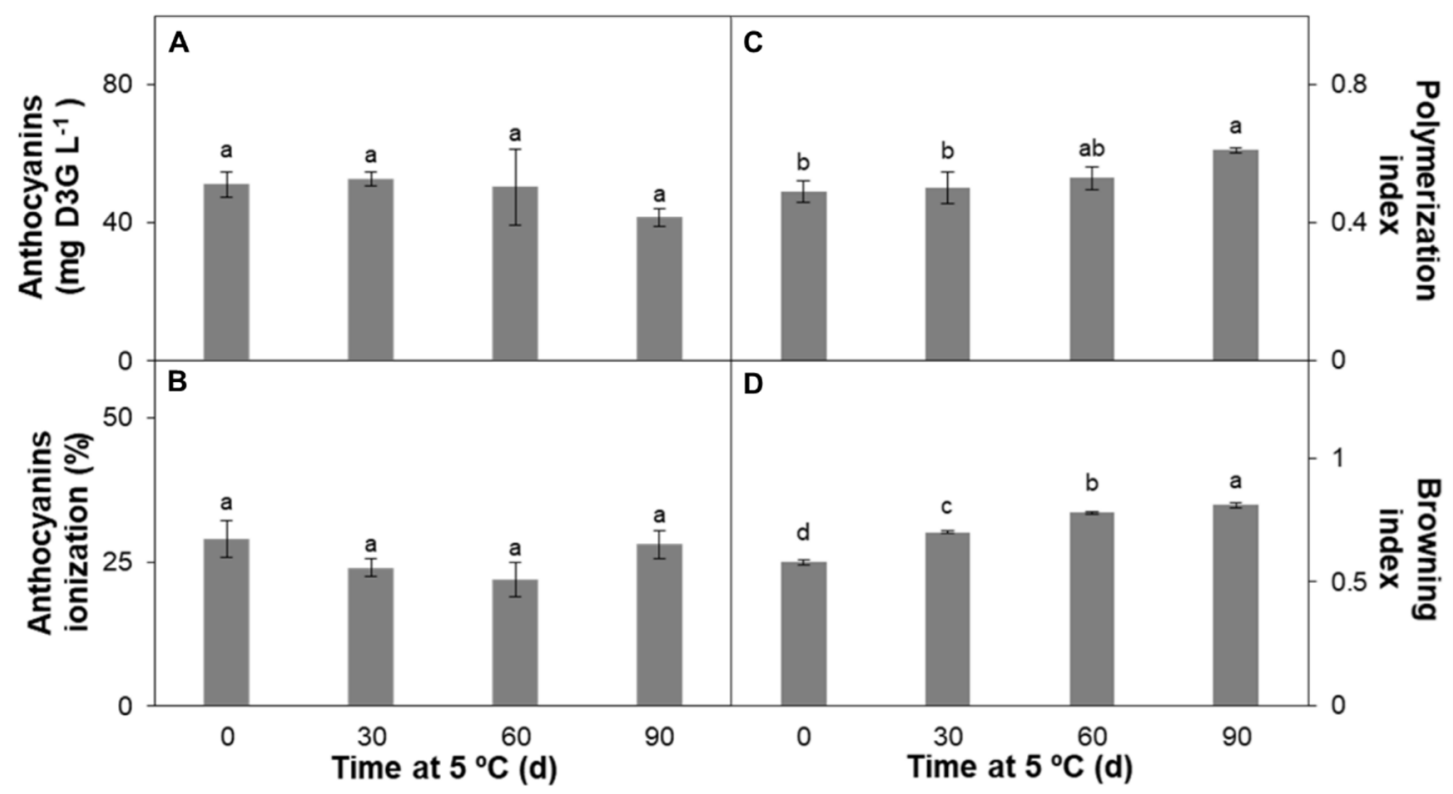

Fig. 4. A. Anthocyanins; B. Anthocyanin ionization (\%); C. Polymerization index and D. Browning index of barberry beers $\left(5 \mathrm{~g} \mathrm{~L}^{-1}\right)$ after bottle storage at $5^{\circ} \mathrm{C}$ for $0,30,60$ and $90 \mathrm{~d}$. Mean \pm standard errors are shown. Letters indicate significant differences based on a Tukey test at a significance level of $p<0.05$.

of their glycosylation and acetylation degree (Ruiz et al., 2010). However, color and stability depend on the matrix where it is present, which is more important than anthocyanin structure (West and Mauer, 2013). Low molecular weight phenolic compounds, which are able to form a co-pigmentation complex through $\pi-\pi$ orbital interactions, may considerably increase anthocyanin stability (Ertan et al., 2020). Some phenolic compounds, commonly found in cereal grains like p-coumaric, synaptic and ferulic acids, may interact with anthocyanins in a beer matrix (Piazzon et al., 2010). Interestingly, ferulic acid, which has been found at higher levels in sour beers compared with other beer styles, has been especially effective as a stabilizer (Fan et al., 2019). However, $\mathrm{pH}$ level is definitely the most important factor affecting anthocyanin stability in foods (West and Mauer, 2013). In fact, it influences the equilibrium between different anthocyanin molecular forms. Such effect results from the relative level of the quinoidal, carbinol/ chalcone and flavylium ionic forms, with the latter being by far the more stable and prevalent at low $\mathrm{pH}$ values (West and Mauer, 2013). Remarkably, $20-30 \%$ of the anthocyanin contents were in flavylium ionic forms (Fig. 4B), exceeding the levels reported in some wines (Tavares et al., 2017). During storage, the ionization degree (ID) decreased between 30 and $60 \mathrm{~d}$ and then increased at $90 \mathrm{~d}$. The low $\mathrm{pH}$ values of sour beer favored high ID levels. Furthermore, the polymerization index (PI) was determined as an estimation of the abundance of brown polymers resistant to $\mathrm{SO}_{2}$ bleaching from anthocyanin degradation (Aleixandre-Tudo et al., 2017). No changes in the PI were recorded until $60 \mathrm{~d}$ (Fig. 4C). After that, an increase in PI was detected. The browning index (BI) increased during storage (Fig. 4D). A high correlation between $\mathrm{BI}$ and $b^{*}$ CIELab color parameter was found $(R=0.910 ; P=0.000)$.

The antioxidant activity of beer was monitored by the $\mathrm{ABTS}^{*+}$ cation method and phenols by FolinCiocalteu molybdenum-tungsten reagent. Both methods showed the same trend for the control and barberry beer (Fig. 5A and 5B), indicating that phenolic compounds represent the most relevant antioxidant source in sour beer. The antioxidant capacity and phenols in the control beer increased c.a. $30 \%$ after $30 \mathrm{~d}$, and then remained constant until $90 \mathrm{~d}$. This contrasts with the reduction of phenolic compounds during storage reported in a previous study (Wannenmacher et al., 2018). This increase may be related to the formation of new high molecular weight phenolic compounds with higher antioxidant activity than single counterparts (Callemien and Collin, 2010). The antioxidant capacity of barberry beer was two-fold higher than the control and remained unchanged throughout storage (Fig. 5A). Sensory analyses of the control and barberry beers are shown in Fig. 5C and 5D, respectively. Sourness 


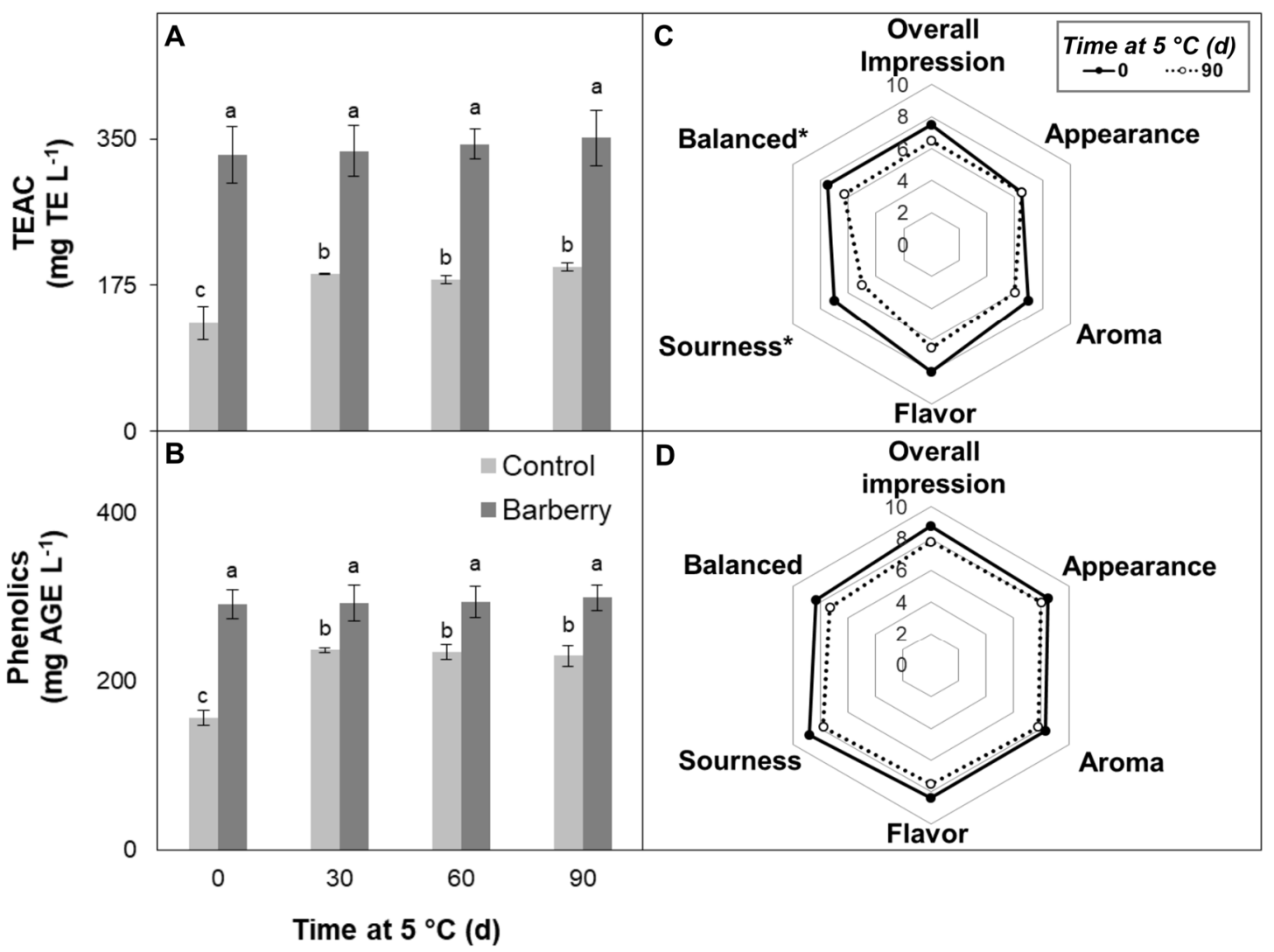

Fig. 5. A. Antioxidant capacity (TEAC); B. Phenolic compounds after bottle storage at $5^{\circ} \mathrm{C}$ for $0,30,60$ and $90 \mathrm{~d}$; and C-D. Sensory scores of the control (C) and barberry beers (D) after bottle storage at $5^{\circ} \mathrm{C}$ for 0 and $90 \mathrm{~d}$. Mean \pm standard errors and means are shown in bar and spider graph, respectively. Letters or asterisks indicate significant differences based on a Tukey test at a level of significance of $p<0.05$.

and balanced attributes decreased in the control after $90 \mathrm{~d}$ storage. No changes in the attributes of barberry beer were detected.

\section{CONCLUSIONS}

Freeze-dried barberry powder added in the range of 2.5-10 g per liter caused a marked increase in red color and antioxidant capacity of sour beer. The addition of $5 \mathrm{~g} \mathrm{~L}^{-1}$ of barberry resulted in a red ruby beer with high fruitlike attributes, showing a two-fold increase in antioxidant capacity without relevant changes in $\mathrm{pH}$, acidity, or density. The barberry beer proved stable after $90 \mathrm{~d}$ storage at $5^{\circ} \mathrm{C}$, with no changes in beer color, anthocyanin content, antioxidant capacity, $\mathrm{pH}$, acidity, or density. Color stability was related to the relatively low $\mathrm{pH}$ level of the sour beer analyzed, which allowed for a high content of anthocyanins in their stable ionized flavylium form. The results show that barberry can add value to beer. Brewing with barberry resulted in a ruby-red color, antioxidant and anthocyanin concentrated sour-beer with high stability.

\section{ACKNOWLEDGMENTS}

The authors thank the Agencia Nacional de Promoción Científica y Tecnológica (PICT 20153690) and Universidad de Morón, Argentina (PIO/17-06-MA-009) for their financial support, and Laurus ${ }^{\circledR}$ for providing technical and infrastructure support.

\section{Data availability statement}

The data that support the findings of this study are available from the corresponding author upon reasonable request. 


\section{LITERATURE CITED}

Ahliha, A.H., F. Nurosyid, A. Supriyanto, and T. Kusumaningsih. 2018. Optical properties of anthocyanin dyes on $\mathrm{TiO}_{2}$ as photosensitizers for application of dye-sensitized solar cell (DSSC). In IOP Conference Series: Materials Science and Engineering 333, 012018. IOP Publishing. $\quad$ https://doi.org/10.1088/1757899X/333/1/012018

Aleixandre-Tudo, J. L., A. Buica, H. Nieuwoudt, J.L. Aleixandre, and W. du Toit. 2017. Spectrophotometric analysis of phenolic compounds in grapes and wines. J. Agric. Food Chem. 65(20): 4009-4026. https://doi. org/10.1021/acs.jafc.7b01724

AOAC. 2012. Official Methods of Analysis. Association of Official Analytical Chemists (AOAC), $19^{\text {th }}$ ed. Washington, DC, USA.

Caballero, I., C.A Blanco, and M. Porras. 2012. Iso- $\alpha$-acids, bitterness and loss of beer quality during storage. Trends Food Sci Technol 26:21-30.https://doi.org/10.1016/j. tifs.2012.01.001

Callemien, D., and S. Collin. 2010. Structure, organoleptic properties, quantification methods, and stability of phenolic compounds in beer- A review. Food Rev. Int. 26:1-84. https://doi.org/10.1080/87559120903157954

Chervina, N.M., I.V. Geide, and I.S. Selezneva. 2019. The study of possible use of lactic bacteria in brewing. AIP Conference Proceedings, 2174, 020099. https://doi. org/10.1063/1.5134250

Dysvik, A., K.H. Liland, K.S. Myhrer, B. Westereng, E.O. Rukke, G. De Rouck, et al. 2019. Pre-fermentation with lactic acid bacteria in sour beer production. J. Inst. Brew. 125:342-356. https://doi.org/10.1002/ jib.569

Ertan, K., M. Türkyılmaz, and M. Özkan. 2020. Color and stability of anthocyanins in strawberry nectars containing various copigment sources and sweeteners. Food Chem. 310:125856. https://doi.org/10.1016/j. foodchem.2019.125856

Fan, L., Y. Wang, P. Xie, L. Zhang, Y. Li, and J. Zhou. 2019. Copigmentation effects of phenolics on color enhancement and stability of blackberry wine residue anthocyanins: chromaticity, kinetics and structural simulation. Food Chem. 275:299-308. https:// doi.org/10.1016/j.foodchem.2018.09.103

Fitzpatrick, L., G. Strong, D. Houseman, and M. Dixon. 2017. Competition Handbook. Beer Judge Certification Program, Inc. Available at www.bjcp.org (Accessed 27-12-2020)
Forde, G. 2017. Examining craft brewing as a social innovation process. Master's Thesis Aalto University School of Arts, Design and Architecture Department of Design. Helsinki, Finland. http://urn.fi/ URN:NBN:fi:aalto-201707046140

Gómez-García, R., D.A. Campos, A. Oliveira, C.N. Aguilar, A.R. Madureira, and M.Pintado. 2021. A chemical valorisation of melon peels towards functional food ingredients: Bioactives profile and antioxidant properties. Food Chem. 335: 127579. https:// doi.org/10.1016/j.foodchem.2020.127579

Guido, L.F. 2019. Brewing and Craft Beer. Beverages 5: 51. https://doi.org/10.3390/ beverages5030051

Horincar, G., E. Enachi, C. Bolea, G. Râpeanu, and I. Aprodu. 2020. Value-added lager beer enriched with eggplant (Solanum melongena L.) Peel Extract. Molecules 25:731. https://doi. org/10.3390/molecules25030731

Jin, X., M. Chen, L. Yi, H. Chang, T. Zhang, L. Wang, et al. 2014. Delphinidin-3-glucoside protects human umbilical vein endothelial cells against oxidized low-density lipoprotein-induced injury by autophagy upregulation via the AMPK/SIRT1 signaling pathway. Mol Nutr Food Res 58:1941-1951. https://doi.org/10.1002/mnfr.201400161

Kawa-Rygielska, J., K. Adamenko, A.Z. Kucharska, P. Prorok, and N. Piórecki. 2019. Physicochemical and antioxidative properties of cornelian cherry beer. Food Chem. 281:147-153. https://doi.org/10.1016/j. foodchem.2018.12.093

Martínez, A., S. Vergara, M. Herranz-López, Martí, M. Valero, V. Micol, and D. Saura. 2017a. Kinetic changes of polyphenols, anthocyanins and antioxidant capacity in forced aged hibiscus ale beer. J. Inst. Brew. 123:58-65. https://doi.org/10.1002/jib.387

Martínez, A., S. Vegara, N. Martí, M. Valero, and D. Saura. 2017b. Physicochemical characterization of special persimmon fruit beers using bohemian pilsner malt as a base. J. Inst. Brew. 123:319-327. https://doi. org/10.1002/jib.434

Muche, B.M., R.A. Speers, and H.P. Rupasinghe. 2018. Storage temperature impacts on anthocyanins degradation, color changes and haze development in juice of "Merlot" and "Ruby" grapes (Vitis vinifera). Front Nutr 5:100. https://doi.org/10.3389/fnut.2018.00100

Patraşcu, L., I. Banu, M. Bejan, and I. Aprodu. 2018. Quality parameters of fruit beers available on romanian market. Scientific study \& research 19:323-335. http://pubs.ub.ro/dwnl. php?id=CSCC6201803V03S01A0008 
Petrón, M. J., A.I. Andrés, G. Esteban, and M.L.Timón. 2021. Study of antioxidant activity and phenolic compounds of extracts obtained from different craft beer byproducts. J. Cereal Sci. 98: 103162. https://doi. org/10.1016/j.jcs.2021.103162

Piazzon, A., M. Forte, and M. Nardini. 2010. Characterization of phenolics content and antioxidant activity of different beer types. J Agric Food Chem 58:10677-10683. https://doi.org/10.1021/jf101975q

Rodoni, L.M., V. Feuring, M.J. Zaro, G.O. Sozzi, A.R. Vicente, and M.E. Arena. 2014. Ethylene responses and quality of antioxidant-rich stored barberry fruit (Berberis microphylla). Sci. Hortic. 179:233-238.https://doi.org/10.1016/j. scienta.2014.09.023

Ruiz, A., I. Hermosin-Gutierrez, C. Mardones, C. Vergara, E. Herlitz, M. Vega, et al. 2010. Polyphenols and antioxidant activity of calafate (Berberis microphylla) fruits and other native berries from Southern Chile. J Agric Food Chem 58: 6081-6089. https://doi.org/10.1021/jf100173x

Sadowska, K., J. Andrzejewska, and L. Klóska. 2017. Influence of freezing, lyophilisation and air-drying on the total monomeric anthocyanins, vitamin $\mathrm{C}$ and antioxidant capacity of selected berries. Int. J. Food Sci. Technol. 52:1246-1251. https://doi. org/10.1111/ijfs.13391

Schuina, G.L., J.O.F. Quelhas, G.B.M. De Carvalho, and V.L. Del Bianchi. 2020. Use of carqueja (Baccharis trimera (Less.) DC. Asteraceae) as a total substitute for hops in the production of lager beer. J. Food Process. Preserv. 44:14730 https://doi.org/10.1111/jfpp.14730

Strong, G., and K. England. (eds). 2015. Beer Judge Certification Program: 2015 style guidelines. Access 2020 in: https://www.bjcp. org/docs/2015_Guidelines_Beer.pdf

Tavares, M., A.M. Jordão, and J.M. Ricardo-daSilva. 2017. Impact of cherry, acacia and oak chips on red wine phenolic parameters and sensory profile. OENO One 51: 329-342. 10.20870/oeno-one.2017.51.4.1832
Tonsmeire, M. 2014. American sour beer: Innovative techniques for mixed fermentations. Brewers Publications. PO Box 1679, Boulder, Colorado 80306-1679.

Ulloa, P. A., J. Vidal, M.I. Ávila, M. Labbe, S. Cohen, and F.N. Salazar. 2017. Effect of the addition of propolis extract on bioactive compounds and antioxidant activity of craft beer. J. Chem. 6716053. https://doi. org $/ 10.1155 / 2017 / 6716053$

Wannenmacher, J., M. Gastl, and T. Becker. 2018. Phenolic substances in beer: Structural diversity, reactive potential and relevance for brewing process and beer quality. Compr. Rev. Food Sci. Food Saf. 17:953-988. https:// doi.org/10.1111/1541-4337.12352

West, M.E., and L.J. Mauer. 2013. Color and chemical stability of a variety of anthocyanins and ascorbic acid in solution and powder forms. J Agric Food Chem 61:4169-4179. https://doi.org/10.1021/jf400608b

Wray, E. (2020). Common faults in beer. In The Craft Brewing Handbook (217-246). Woodhead Publishing. https://doi.org/10.1016/B978-008-102079-1.00008-4

Yeo, H.Q., and S.Q. Liu. 2014. An overview of selected specialty beers: Developments, challenges and prospects. Int. J. Food Sci. Technol. 49:1607-1618. https://doi.org/10.1111/ijfs.12488

Zapata, P.J., A. Martínez-Esplá, A. GironésVilaplana, D. Santos-Laxa, L. NogueraArtiagab, and A.A. Carbonell-Barrachina. 2019. Phenolic, volatile, and sensory profiles of beer enriched by macerating quince fruits. LWT 103:139-146. https://doi.org/10.1016/j. lwt.2019.01.002

Zhao, H., W. Chen, J. Lu, and M. Zhao. 2010. Phenolic profiles and antioxidant activities of commercial beers. Food Chem. 119:11501158. https://doi.org/10.1016/j.foodchem.2009.08.028 